\title{
Working
}

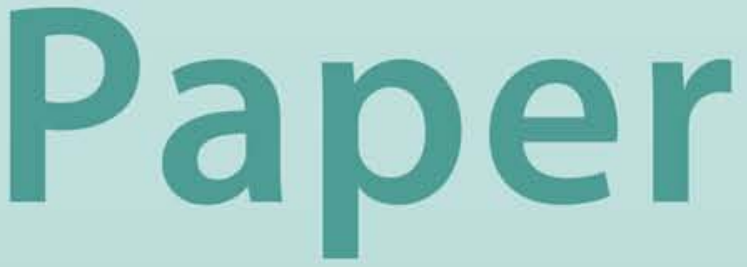




\section{Distributional Effects of Oil Price Changes on Household Expenditures: Evidence from Mali}

Kangni Kpodar 


\title{
IMF Working Paper
}

\author{
African Department \\ Distributional Effects of Oil Price Changes on Household Expenditures: \\ Evidence from Mali \\ Prepared by Kangni Kpodar ${ }^{1}$
}

Authorized for distribution by Arend Kouwenaar

March 2006

\begin{abstract}
This Working Paper should not be reported as representing the views of the IMF. The views expressed in this Working Paper are those of the author(s) and do not necessarily represent those of the IMF or IMF policy. Working Papers describe research in progress by the author(s) and are published to elicit comments and to further debate.

Using an input-output approach, this paper assesses the distributional effects of a rise in various petroleum product prices in Mali. The results show that, although rising gasoline and diesel prices affect mainly nonpoor households, rising kerosene prices are most harmful to the poor. Overall, the impact of fuel prices on household budgets displays a U-shaped relationship with expenditure per capita. Regardless of the oil product considered, highincome households would benefit disproportionately from oil price subsidies. This suggests that a petroleum price subsidy is an ineffective mechanism for protecting the income of poor households compared with a targeted subsidy.
\end{abstract}

JEL Classification Numbers: H2, D57, R2

Keywords: Oil; subsidies; input-output analysis; household welfare

Author(s) E-Mail Address: roland.kpodar@u-clermont1.fr

\footnotetext{
${ }^{1}$ The study was undertaken during a summer internship at the IMF. The author would like to thank Chris Lane for many helpful comments and suggestions. The author is also grateful to David Coady, Mark Ellyne, Helmut Franken, Sylviane Guillaumont, Arend Kouwenaar, Jean-Claude Nachega, David Newhouse, Armin Schwidrowski, Saji Thomas, and seminar participants at the IMF. The usual disclaimer applies.
} 


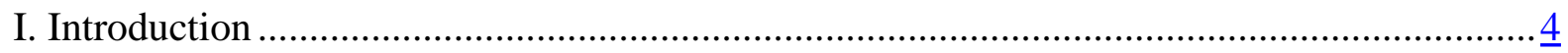

II. How Domestic Oil Prices Are Linked to International Oil Prices Changes.......................... $\underline{5}$

A. Factors Affecting Domestic Oil Prices .....................................................................

B. The Issues Raised by the Pass-Through Mechanism in Mali ......................................

III. The Consequences of Rising Oil Prices for Households..................................................... 9

A. Methodology and Data .................................................................................... 10

B. Data and Descriptive Statistics ............................................................................ 12

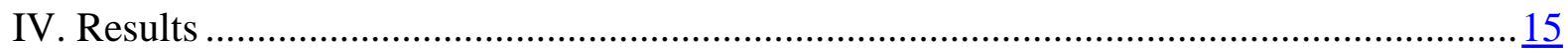

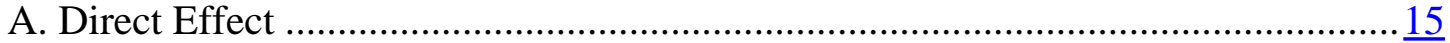

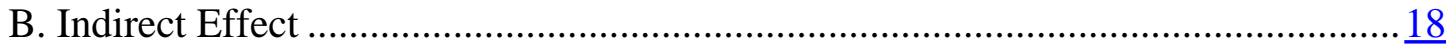

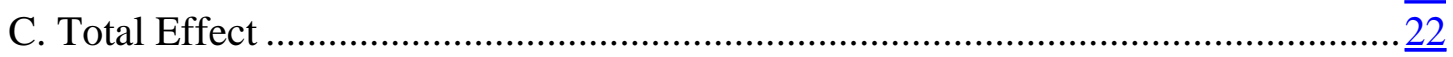

D. Results for Mali Versus Other Countries ..............................................................24

V. Conclusion and Policy Implications ...........................................................................

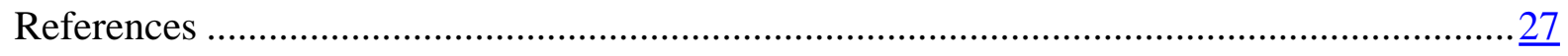

Tables

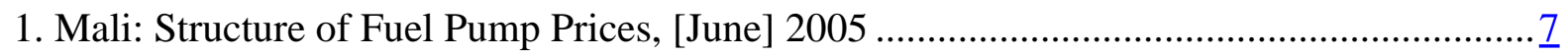

2. Distribution of Household Expenditures ..................................................................... 13

3. Equipment Ownership and Oil Consumption.................................................................... 14

4. Household Budget Shares of Energy Spending by Product ................................................. 16

5. Direct Expenditure Effects of Oil Price Increases............................................................... 16

6. Budget Shares of Petroleum Products and Direct Expenditure Effects, by Quintile and Urban/Rural ............................................................................................................. 18

7. Share of Household Expenditure on Different Goods and Services by Household Income Quintile .............................................................................................................. 19

8. Indirect Price and Expenditure Effects by Sector............................................................. 20

9. Indirect Expenditure Effects by Quintile, Rural and Urban ................................................21

10. Total Direct and Indirect Expenditure Effects by Quintile, Urban and Rural....................23

11. Relative Importance of Direct and Indirect Effects........................................................ 24

12. Indirect Expenditure Effects by Quintile, Rural and Urban: Distribution Effects of Controlled Electricity Price …………………………………………………………... 24

Figures

1. Changes in the International Oil Price, 2001-05 ............................................................ $\underline{5}$

2. Mali: Pass-Through of World Oil Prices, 2002-05 ....................................................... $\underline{8}$

3. Mali: World Oil Price Trend (HP Filter) and Changes in Domestic Oil Price, 2002-05 ....... $\underline{9}$

4. Shares of Sectors in the Total Intermediate Consumption of Oil Products, 1998 .............15

5. Direct Expenditure Effects: A Nonparametric Representation..................................... 17 
6. Price Changes of Commodities in Other Sectors Due to a 34 Percent Increase in Oil

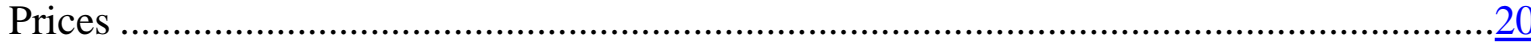

7. Indirect Expenditure Effects: A Nonparametric Representation ..................................... 21

8. Total Expenditure Effects: A Nonparametric Representation ....................................... 23

Appendices

Appendix I. The Model …........................................................................................ 29

Appendix II. Distributional Effects of Oil Price Changes: Selected Country Studies ....... $\underline{31}$ 


\section{INTRODUCTION}

For many developing countries, the increase in oil prices over the past few years has made structural reform of the domestic petroleum pricing system a critical component of their macroeconomic policies. From a relative low price of US\$26 a barrel in December 2001, oil prices have increased by about 130 percent, reaching US\$60 a barrel by June 2005. Although in some countries, this large oil price increase may have been partly offset by exchange rate movements (notably, the weakening of the U.S. dollar against the euro), it has also had a major socioeconomic impacts. Many governments have been reluctant to pass on to consumers a rise in international oil prices because of the potential for social resistance to a policy that could hurt the poor. However, if they do not pass on the higher prices, their countries could experience a significant fiscal burden, which, in turn, could oblige governments to cut social spending.

The purpose of this paper is to quantify the magnitude and distributional effects of a rise in oil prices on the real income of households in Mali and also to evaluate the effectiveness of subsidies in protecting poor households. In Mali, oil subsidies are implicit and result from low, government-controlled petroleum prices. Given the budgetary cost of such a policy, nearly 2 percent of GDP in 2004, ${ }^{2}$ it is important to assess the level and distribution of the effects of oil price hikes on household welfare to determine if the subsidies are serving their intended purpose.

Mali is large, poor, and landlocked and is highly dependent on imported oil products. In 2003, income per capita was about US\$260. The main sources of energy are wood, charcoal, and petroleum oil products, with the latter accounting for 61.5 percent of the country's total energy use. Its total supply of petroleum products was 544,000 tons in 2001, of which diesel represented 51 percent; gasoline, 17 percent; fuel oil, 18 percent; and kerosene, 8 percent. Thus, Mali is one of the low-income countries most vulnerable to oil price shocks. Its vulnerability, measured by the ratio of net oil imports to GDP, reached 5.4 percent in 2001, compared with an average of 3.34 percent for all oil importers and 3.97 percent for landlocked oil importers. Mali's vulnerability mainly results from the fact that the country is not an oil producer. That vulnerability is also a product of geography: its nearest ports are nearly 1,000 kilometers from the capital, and about one-third of its electricity is generated from oil.

To take into account both the direct and indirect effects of oil price increases on household welfare, we combine a household survey data and a sectoral input-output data set. Households in Mali use kerosene for lighting and cooking and gasoline for transport; thus, higher oil prices lead directly to a decrease in their real incomes. Higher oil prices also affect households indirectly, through a rise in the prices of good and services of other sectors that use oil products as intermediate goods. Depending on how much of their budget households spend on oil products and the input-output linkages between the petroleum sector and other sectors, the

\footnotetext{
${ }^{2}$ Of the increase, 0.9 percent is due to the cost of tax differentiation by route of importation, 0.71 percent represents the tax exemption received by the mining sector, and 0.23 percent constitutes the loss of petroleum revenue in 2004, assuming that oil tax rates remained constant between 2003 and 2004.
} 
effect of oil price increases on household income may be substantial, although it varies by income group.

The paper is organized as follows. Section II reviews the major factors behind oil price increases and highlights the implications of low, government-controlled prices. Section III presents the methodology and data used to estimate the impact of oil price hikes on household expenditures. Section IV reports the result of the policy simulation. Section V concludes and offers economic policy recommendations.

\section{How Domestic Oil Prices Are Linked to International Oil Prices Changes}

\section{A. Factors Affecting Domestic Oil Prices}

The authorities control domestic oil product prices by setting a monthly ceiling price. The ceiling price is calculated on the basis of four main factors: crude oil prices, the exchange rate, taxation (an excise tax and a value-added tax), and domestic margins. Below, we discuss the consequences of each factor in Mali's context.

Crude oil. Since 2001, the growing demand for oil and the limited capacity of oil-producing countries to boost their production have caused oil prices to rise significantly. International oil prices rose from US\$26 a barrel in January 2001 to about US\$50 a barrel in March 2005 (Figure 1). Mali does not import crude oil but imports only refined petroleum products. However, refined oil prices closely track crude oil prices when both are denominated in the same currency.

Figure 1. Changes in the International Oil Price, 2001-05

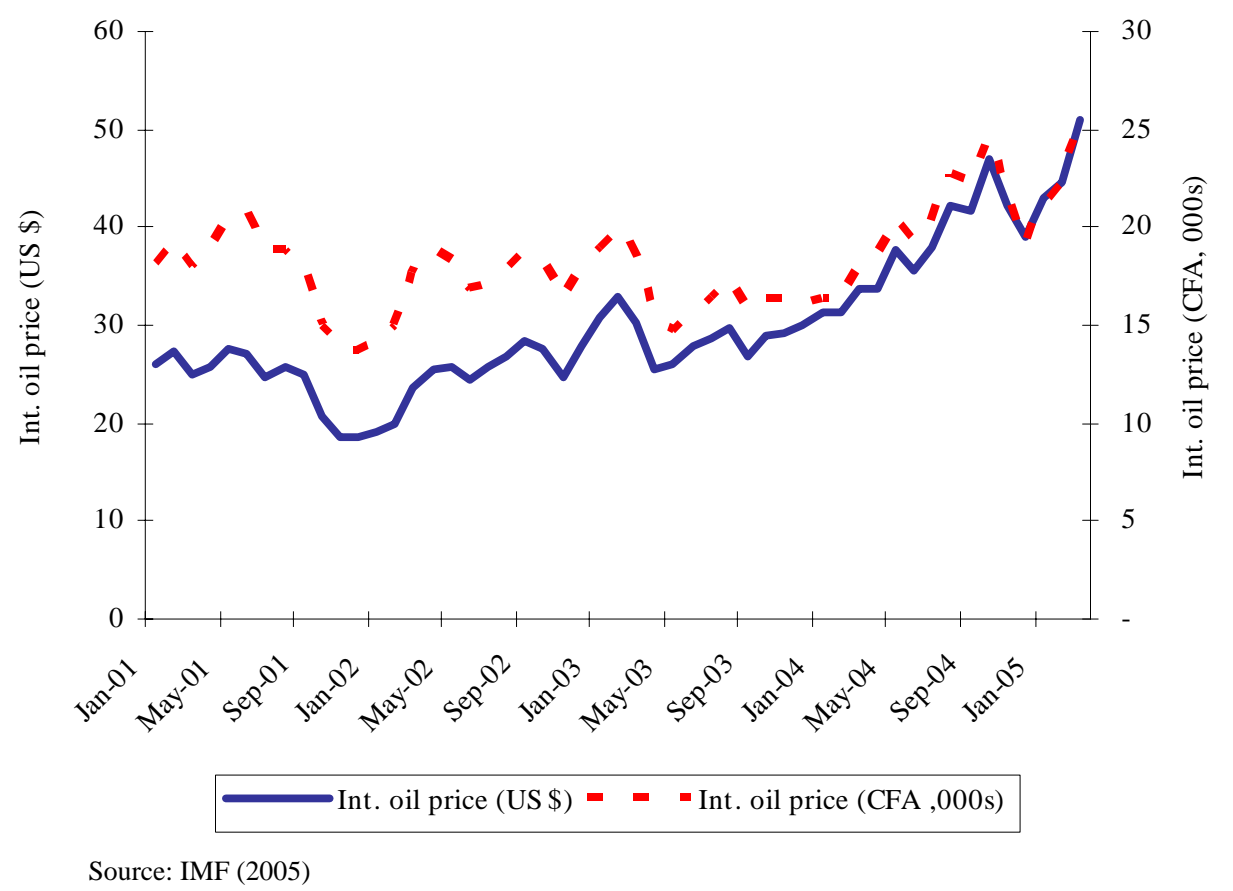


Exchange rate. Because world crude oil prices are denominated in dollars and the CFA franc is pegged to the euro, the recent appreciation of the euro against the dollar has reduced Mali's oil bill. The CFA franc appreciated against the dollar by 23 percent between 2001 and mid-2005, leading to a lower rate of increase in oil prices denominated in CFA francs compared with prices in dollars (Figure 1).

Distribution and retail margins. In May 2005, retail margins represented only 5.2 to 8 percent of pump prices, depending on the oil product. Transport costs accounted for a larger share (9 to 13.2 percent) of oil prices, probably because of long and costly routes of importation (Table 1).

Taxation. A value-added tax (VAT) of 18 percent is applied to all oil products. However, distribution of petroleum products is exempt from the VAT, thus oil products pay VAT at the border on a tax base that includes the c.i.f. value of imports, customs duties, and a specific excise.

The taxe interieure sur les produits pétroliers (TIPP) is the excise tax levied on oil products in Mali. The TIPP represents an important revenue source for the government, with gross receipts amounting to CFAF 30 billion in 2004 (over 1 percent of GDP). It is adjusted monthly by decree of the minister of economy and finance, and the rate differs by product and route of importation.

Kerosene is taxed at a lower TIPP rate. Given that it is consumed primarily by low-income groups, kerosene is taxed at lower rates than other oil products, with the TIPP accounting for 3.9 percent of its pump price compared with 30.9 percent for gasoline (Table 1). The TIPP rate is also lower for diesel than for gasoline because the former is often used for transport and electricity production.

In addition, imports from distant ports such as Cotonou and Lomé ${ }^{3}$ receive favorable tax treatment, owing to the government's desire to diversify supply routes. However, given the cost of the policy of differentiating the TIPP, the government decided to substantially reduce the differentiation between routes from June 2005.

The VAT and TIPP have different implications on the government budget through petroleum revenues, which represent over 20 percent of the total tax revenue. The VAT accounted for 45 percent of petroleum revenues in 2004, whereas the TIPP represented 40 percent of petroleum revenues in the same year. An increase in international oil prices would lead to a rise in the VAT revenues (unless the government changes its tax policy). In contrast, an increase in international price has no effect on the TIPP revenues since the TIPP is an excise tax. However, the TIPP revenues may decline if a substantial increase in domestic oil prices leads to a reduction in oil consumption. When the government changes the tax policy, for example by lowering the TIPP rates to soften domestic oil price increases, it loses potential tax revenues not only because of lower TIPP rates but also because of lower VAT revenues since the VAT rate is applied on the price with the TIPP included. Alternatively, if the TIPP rates

\footnotetext{
${ }^{3}$ Mali imports oil products from the ports of Dakar, Abidjan, Lomé, and Cotonou.
} 
are increased following a drop in international oil prices so that pump prices remain unchanged or decrease more slowly, the result would be an increase in petroleum revenues.

Table 1. Mali: Structure of Fuel Pump Prices, [June] 2005

(In percent of pump prices)

\begin{tabular}{|c|c|c|c|}
\hline & Kerosene & Gasoline & Diesel \\
\hline Supplier price & 60.1 & 34.3 & 49.3 \\
\hline Tax & 21.6 & 48.6 & 31.5 \\
\hline of which: TIPP & 3.9 & 30.9 & 12.1 \\
\hline VAT & 13.3 & 13.3 & 13.1 \\
\hline Transport costs & 13.2 & 9.1 & 11.7 \\
\hline Margins & 5.2 & 8.0 & 7.5 \\
\hline Total & 100.0 & 100.0 & 100.0 \\
\hline
\end{tabular}

Notes: Data for imports from Dakar.

Source: Malian Ministry of Finance.

Currently, the domestic oil price is calculated as follows:

Pump price $=[$ CIF Import Price $*$ DT + TIPP $] *$ VAT + Transport cost + Domestic margin where the CIF import price includes the supplier price and transport cost to the border. The supplier price depends on crude oil price, exchange rate between the euro and the dollar, and refinery cost. DT represents the duty tax.

In Mali, the government has primarily used the TIPP rates to hit targeted pump prices given the change in international oil prices. As a result, an increase in international oil prices may cause the country to lose a significant amount of fiscal revenue depending on the extent to which the TIPP rates are lowered to offset partially the impact of international oil price hikes on consumer prices. Figure 2 shows that in Mali, there was less-than-full pass-through from January 2002 until the beginning of 2003, and that a drop in world prices during 2003 was not passed through to the pump. Thus, consumers paid more than they would have paid if the price drop had been passed through to them and thereby increased government revenue. From mid2004, however, international oil prices rose above domestic prices. 
Figure 2. Mali: Pass-Through of World Oil Prices, 2002-05

(Index, Jan 2002=100)

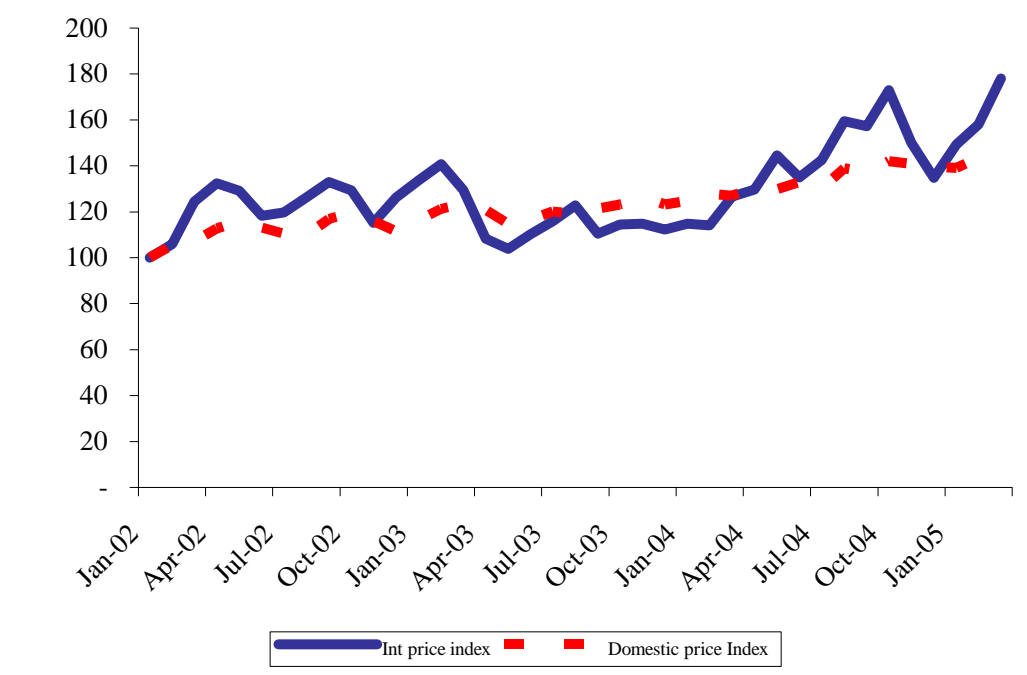

Source: IMF (2005)

\section{B. The Issues Raised by the Pass-Through Mechanism in Mali}

The government has followed an active policy that consists in smoothing fluctuations in domestic oil prices, but the pace of movement remains under the trend of international oil prices. The pass-through of world oil prices to domestic prices appears to be done in a smoothing fashion-sometimes the domestic prices are below world prices and sometimes they are above - and this may be a reasonable strategy for a country that is trying to avoid short-term shocks. Although that strategy may be efficient in the short run, it could be costly in the medium and long run if the domestic price trend is under the international price trend. Figure 3 shows that domestic oil prices in Mali seem not to closely follow the international oil price trend during the period considered. ${ }^{4}$ The trend of domestic oil prices rather tends to be below that of international oil prices, and this may result in a significant cost to the government budget.

\footnotetext{
${ }^{4}$ The international oil price trend was obtained by using the Hodrick-Prescott filter.
} 
Figure 3. Mali: World Oil Price Trend (HP Filter) and Changes in Domestic Oil Price, 2002-05

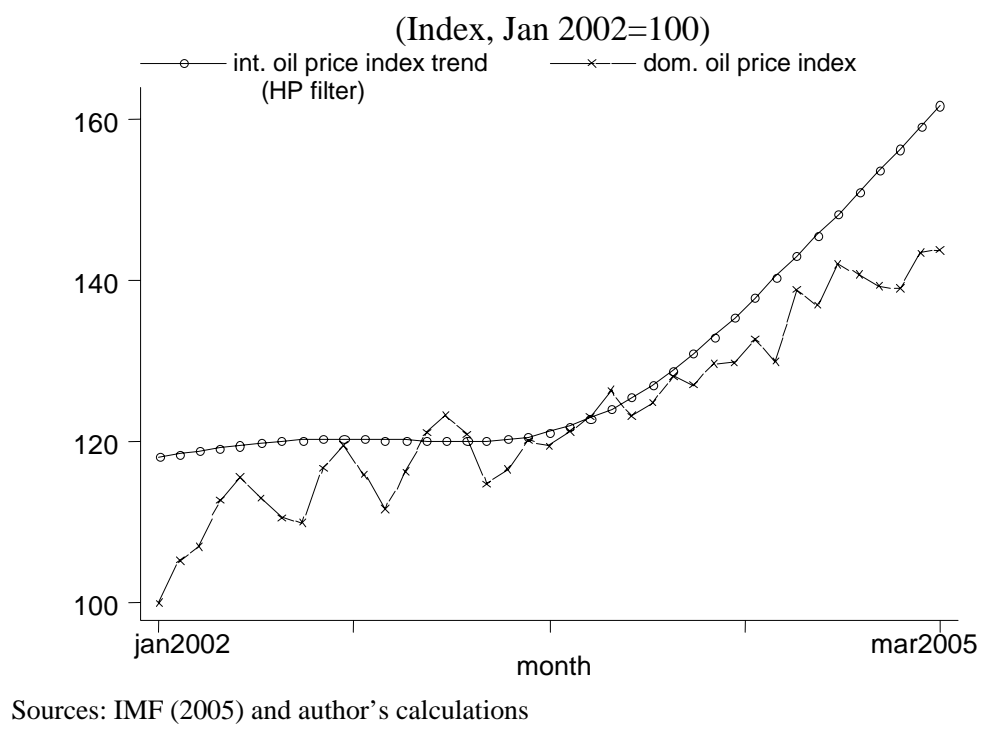

The current oil price policy in Mali raises the question of budget sustainability. International oil prices currently remain high and volatile, and attempting to smooth their impact may be costly if the budget is not able to absorb the shocks. Given the significant share of oil revenues in the tax revenues, volatile oil prices may increase fiscal vulnerability. Mali's pass-through mechanism could be sustainable if the country would save the extra revenues obtained when international oil prices are low and use those financial resources to permit lower domestic petroleum taxes when international oil prices are high. The budget sustainability of current policy is beyond the scope of this paper.

Lower government-controlled petroleum prices may not promote an efficient use of resources and may lower the incentives for households and firms to switch to other energy sources. By reducing the demand for oil products, higher petroleum prices could improve the foreign trade balance and reduce the harmful environmental effects that stem from oil consumption.

However, the gains in efficiency may be reduced when households switch expenditures to other goods that are heavily subsidized or that may have a greater environmental effect. For example, higher prices may lead poor rural households to switch to biomass, resulting in an overexploitation of the country's forests.

An important implication of the pass-through mechanism is its effects on resource distribution (equity). Households will be affected differently by oil price increases and thus by a policy aimed at controlling oil prices. Is that policy favorable to the poor? Or may the impact of that policy on the poor be improved? To address this issue, it is necessary to assess the effect of oil price increases on households, which is the purpose of the next section.

\section{The Consequences of Rising Oil Prices for Households}

Rising oil prices have both a direct and an indirect effect on household real incomes. Oil price increases directly affect household real incomes through the higher prices for the oil products they consume, but also indirectly raise the prices of goods produced by other sectors through 
their input-output linkages with the petroleum sector. The magnitude of the direct effect will be higher for those households who allocate a high proportion of their budget to oil products. Similarly, the indirect effect will be higher for households who devote a significant share of income to goods whose costs are highly influenced by oil prices.

\section{A. Methodology and Data}

\section{The direct expenditure effect}

The budget shares give a first-order indication of the magnitude of income effects resulting from price changes. For a given product, its budget share corresponds to the price elasticity of real income or total spending assuming the volume of demand constant.

$$
b_{i}=\frac{\partial \log Y}{\partial \log P_{i}}
$$

where $Y$ is the level of income or expenditure, $b_{i}$ is the share of spending on good $i$ in total expenditure and $P_{i}$ is the price of good $i$.

For example, a budget share of 0.10 means that a 100 percent increase in price would lead to a 10 percent drop in real income or to a 10 percent increase in household expenditures. The budget shares of oil products determine the direct effect on consumers of the increase in oil prices.

$$
\partial \log Y_{d i r}=\sum_{t=1}^{m} b_{t} * \partial \log P_{t}
$$

where $\partial \log Y_{d i r}$ is the direct expenditure effect (expressed in percentage), $b_{t}$ is the budget shares of the oil product $t, P_{t}$ is the change in the price of oil product $t$, and $m$ is the number of oil products consumed by households.

\section{The indirect expenditure effect and the input-output approach}

To evaluate the indirect effect, we need to calculate the price rises resulting from the oil price increases of all other final goods purchased by households. The share of household expenditures on each of these final goods multiplied by their respective price changes gives a first-order estimate of the increased cost for purchasing the identical basket of goods before and after the oil price rises. The formula of the indirect effect is then similar to that of the direct effect:

$$
\partial \log Y_{\text {ind }}=\sum_{i=1}^{n-m} b_{i} * \partial \log P_{i}
$$

where $\partial \log Y_{\text {ind }}$ is the indirect expenditure effect (expressed in percentage), $b_{i}$ is the budget shares of final goods other than oil products, $P_{i}$ is the change in the price of good $i, n$ and $m$ are respectively the number of final goods and the number of oil products.

To compute the change in commodity prices following a change in oil prices, we follow the input-output approach adopted by Coady and Newhouse (2005). The authors consider three broad classifications of sectors according to the relationship between higher production costs 
and output prices: cost-push sectors, traded sectors, and controlled sectors. First, cost-push sectors are those in which higher input costs are pushed fully through to output prices. Nontraded sectors are good examples of this category. Second, traded sectors are those where output prices are determined by world prices and trade taxes. ${ }^{5}$ Accordingly, higher input costs lead to lower factor prices or lower profits, other things being equal. Finally, in controlled sectors, output prices are controlled by the government. In these sectors, output prices remain unchanged, so that higher input costs would reduce factor prices, profits, or government tax revenue.

To simplify our analysis, we do not make a distinction between traded and nontraded sectors. That makes sense in this context, because we are looking at the effect of an increase in international oil prices in a country where there is no domestic production of petroleum. Many imported goods are not produced domestically, and transport costs affect the prices of both domestic and imported goods.

We then consider two categories of sectors: the noncontrolled sectors and the controlled sectors. For noncontrolled sectors, the relationship between user and producer prices is given by:

$$
P_{n c}^{u}=P_{n c}^{p}+t_{n c}
$$

where $P_{n c}^{u}$ is the price paid by consumers, $P_{n c}^{p}$ is the price received by producers, ${ }^{6}$ and $t_{n c}$ is the tax imposed by the government. ${ }^{7}$ Changes in the user prices are then given by:

$$
\Delta P_{n c}^{u}=\Delta P_{n c}^{p}+\Delta t_{n c} .
$$

For controlled sectors, producer prices are determined by the government. The change in consumer prices is equal to the change in producer prices plus the change in tax.

$$
\Delta P_{c}^{u}=\Delta P_{c}^{p}+\Delta t_{c}
$$

where $\Delta P_{c}^{u}$ is the change in consumer prices, $\Delta P_{c}^{p}$ is the change in producer prices, and $\Delta t_{c}$ is the change in tax on controlled-sector commodities. As we are not looking for the effect of a change in tax policy, we assume that tax remains constant: $\Delta t_{c}=\Delta t_{n c}=0$.

The technology of production is captured by an input-output coefficient matrix $A$, with $a_{i j}$ denoting the cost of input $i$ in producing one unit of output $j$. Also, $a_{i j}$ represents the change in the production cost of a unit of $j$ resulting from a unit change in the price of input $i$. This implies a Leontief production function, where the firm's demand for inputs is relatively insensitive to the changes in input prices.

Using the input-output coefficient matrix and assuming that factor prices are constant, the change in producer prices is derived as:

\footnotetext{
${ }^{5}$ Foreign goods are assumed to be perfectly competitive with domestically produced traded goods.

${ }^{6}$ Producer prices are a function of intermediate goods costs and factor prices.

${ }^{7}$ Note that $t$ is a trade tax when we consider traded goods, but a domestic tax when we consider nontraded goods. A tax on domestic production of traded goods does not affect user prices, but reduces producer prices.
} 


$$
\begin{aligned}
& \Delta P_{n c}^{p}=A_{3}^{\prime} \cdot \Delta P_{c}^{p}+A_{4}^{\prime} \cdot \Delta P_{n c}^{p}, \\
& (n-p, 1) \quad(n-p, p) \cdot(p, 1) \quad(n-p, n-p) \cdot(n-p, 1) .
\end{aligned}
$$

where $A_{3}^{\prime}$ is the matrix of the input requirements from the $p$ controlled sectors for the production of one unit of output in each $n-p$ noncontrolled sectors, $n$ being the total number of sectors. $A_{4}^{\prime}$ is the square matrix of the input-output coefficients of the $n-p$ noncontrolled sector (see Appendix I for more details).

By rearranging (4), we obtain the following equation that gives the effect of a change in controlled prices (for instance, a change in oil prices) on the prices of noncontrolled sectors:

$$
\Delta P_{n c}^{p}=\left(I-A_{4}^{\prime}\right)^{-1} \cdot A_{3}^{\prime} \cdot \Delta P_{c}^{p} .
$$

The input-output model has significant advantages. Relative to a computable general equilibrium (CGE) model, it requires fewer data. It is also easy to implement and capable of providing valuable information on the magnitude and distributional effects of the impact of marginal price reforms on household real incomes.

However, we note some caveats about this methodology. First, we assume that the level of consumption is constant and that there are no substitution effects. We ignore second-order effects (substitution effects) owing to the lack of data necessary to estimate a system of price elasticities. In other words, our analysis does not take into account the fact that consumers will change their consumption habits in response to the initial price shock and that producers will alter their use of factors of production. Given that there are few, if any, close substitutes for petroleum products, and given the existing level of technology, this assumption appears reasonable in the short run. Also, several studies find that oil demand is highly price-inelastic in the short term (Cooper, 2003; Alves and Bueno, 2003; Gately and Streifel, 1997). In the medium and long run, the first-order effects will nonetheless tend to overestimate the adverse income loss that stems from price increases. Second, we calculate the knock-on effects on real prices by assuming that the increases in oil prices are passed on fully by other sectors of the economy. These may be considered maximum short-run price rises. Third, unlike the CGE model, the input-output model does not take into account the labor market effects of producer price changes. Finally, the usual limitations of the input-output hypothesis apply. ${ }^{8}$

\section{B. Data and Descriptive Statistics}

The data used in this paper are from the Mali 2000-01 household survey and the 1998 inputoutput table.

\section{The 2000-01 household survey}

\footnotetext{
${ }^{8}$ The input-output table is based on the following assumptions: homogeneity of output, no substitution between inputs, fixed proportion between inputs and outputs, absence of economies of scale, exogeneity of primary inputs, and final demand components.
} 
The survey consists of 4,966 households, 63 percent of which are in rural areas. A two-stage random sampling procedure was used to draw the sample of households. First, the country was divided into 12,000 districts, ${ }^{9}$ from which 750 were randomly selected. Second, 10 households were randomly selected within each district, resulting in a sample of 7,500 households. However, only 4,966 households were completely surveyed.

The data set exhibits considerable divergences between urban and rural households in terms of the level and composition of spending (Table 2). The average expenditure per capita in urban areas is more than double that in rural areas, partially because of the larger size of rural households. Regarding the expenditure structure, food dominates consumption, particularly in rural areas. Spending on housing, energy, and water is relatively important for urban households; the corresponding budget share is about 2.5 times higher than that of rural households. In urban areas, oil consumption is devoted largely to transport purposes, whereas in rural areas oil is used primarily to provide lighting.

Table 2. Distribution of Household Expenditures (In percent, unless otherwise noted)

\begin{tabular}{lrrr}
\hline & All & Urban & Rural \\
\hline Household characteristics & & & \\
Average expenditure per capita (in CFA francs) & 135,790 & 224,390 & 104297 \\
Household size (average number of person) & 14.8 & 12.4 & 15.7 \\
Household expenditures & & & \\
Food & 71.6 & 67.7 & 75.9 \\
Clothing & 5.7 & 5.7 & 5.6 \\
Housing, water, and energy & 7.4 & 10.4 & 4.2 \\
Of which: oil products & 1.0 & 0.8 & 1.3 \\
Furniture and household accessories & 1.1 & 0.9 & 1.3 \\
Health & 2.3 & 2.1 & 2.4 \\
Transport and communication & 5.7 & 7.0 & 4.2 \\
Of which: oil products & 2.0 & 3.0 & 1.0 \\
Education & 0.5 & 0.8 & 0.3 \\
Other goods and services & 5.8 & 5.5 & 6.1 \\
\hline Total & 100.0 & 100.0 & 100.0 \\
\hline
\end{tabular}

Source: Mali, 2000-01 household survey.

In addition to household income levels, equipment ownership helps to explain oil consumption (Table 3). Expenditure per capita is negatively correlated with kerosene budget shares and positively correlated with gasoline and diesel budget shares. Holding constant the level of expenditure per capita, agricultural households that own a tractor or a cultivator tend to consume more oil products. Similarly, households that possess a car or a moped tend to have higher petroleum consumption. Data also reveal that household's access to electricity is negatively associated with kerosene consumption.

\footnotetext{
${ }^{9}$ In rural areas, a district is defined as a geographic area where 800 to 1,000 persons are living, whereas in urban areas the number of persons in each district ranges from 1,000 to 1,500 .
} 
Table 3. Equipment Ownership and Oil Consumption

\begin{tabular}{lcccc}
\hline & Total & Kerosene & Gasoline & Diesel \\
\hline Expenditure per capita & + & - & + & + \\
Equipment & & & & \\
$\quad$ Tractor & + & $\mathrm{ns}$ & + & + \\
Cultivator & + & $\mathrm{ns}$ & + & + \\
Mill & + & $\mathrm{ns}$ & + & + \\
Generator & + & - & + & $\mathrm{ns}$ \\
Car & + & - & + & + \\
Moped & + & - & + & + \\
Pirogue (a canoe-like boat) & $\mathrm{ns}$ & + & - & $\mathrm{ns}$ \\
Access to electricity & + & - & + & + \\
Power-driven pump & + & - & - & + \\
\hline
\end{tabular}

Source: Mali, 2000-01 household survey

Notes: Using OLS, oil spending shares are regressed on the level of expenditure per capita (log) and a dummy variable for each piece of equipment. Sign of coefficients are reported. "ns" means nonsignificant.

\section{The 1998 input-output table}

Because the 2000 input-output table is not available, we use the input-output table for 1998 and assume that the structure of the economy did not change dramatically between 1998 and 2000. This assumption seems reasonable because, to our knowledge, the Malian economy did not experience any major technological shocks during that period.

The petroleum sector is strongly linked to other sectors in the economy and has the highest sum of domestic input coefficients. The most oil-intensive sector consists of services intended for the agricultural sector, ${ }^{10}$ with a per unit requirement of 0.29 , followed by the electricity and transport sectors, which have, respectively, 0.27 and 0.19 per unit requirements. A sector's dependence on oil products determines the increase in the cost of production following a rise in oil prices.

\section{Although firms consume a major share of oil products, household fuel consumption is also significant. All the resources of the petroleum sector are imported. Roughly 20 percent of oil products are consumed by households, 76 percent are used by firms as} intermediate goods, and 4 percent are exported. Among the sectors, transport and metallurgy consume the largest shares of oil products (Figure 4). Surprisingly, the public sector seems to consume more oil products than the electricity sector. The mining sector and the exportoriented agricultural sector consume relatively small shares of oil products; as a result, these two sectors benefit less than other sectors from low domestic oil prices.

\footnotetext{
${ }^{10}$ They include coffee bean hulling, protection and treatment of crops, tool and agricultural machine rental.
} 
Figure 4. Shares of Sectors in the Total Intermediate Consumption of Oil Products, 1998

(In percent)

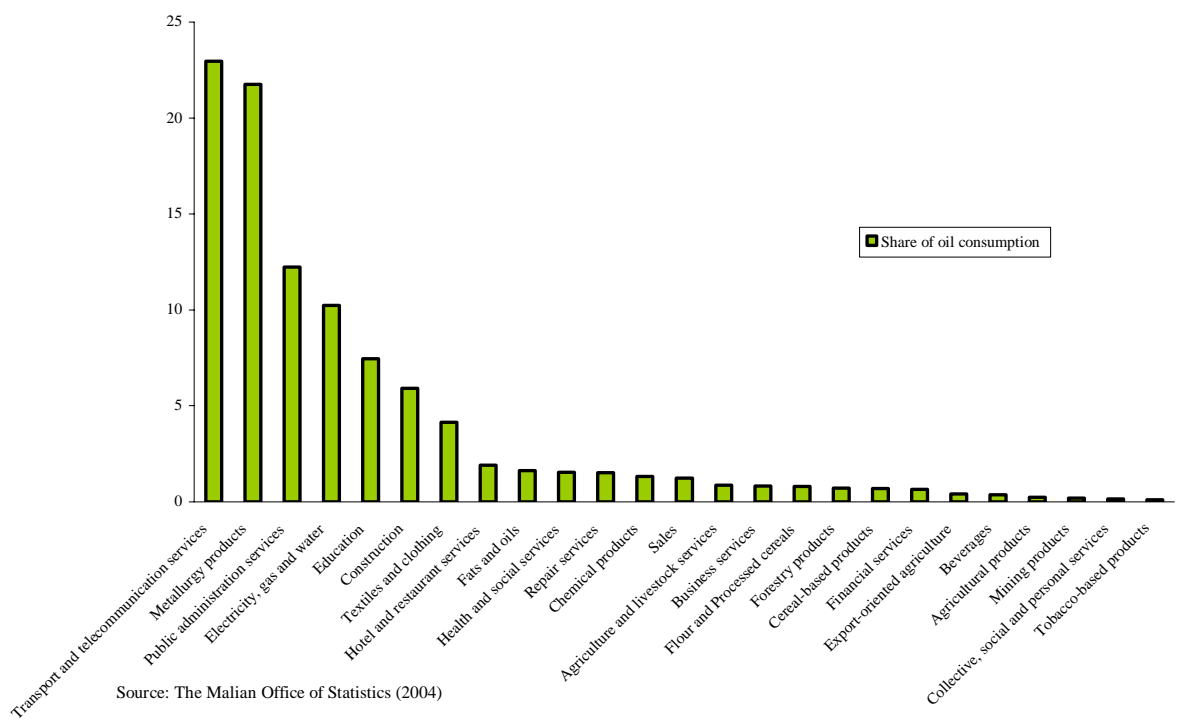

\section{RESUlTS}

In this section, we simulate a 34 percent rise in oil prices corresponding to the change in international oil prices expressed in domestic currency between 2001 and 2005. We assume that international price changes are passed through to domestic prices. First, we present the distribution of the direct expenditure effects. We next examine the indirect distributional effects caused by the increase in other commodity prices. Finally, we highlight the distribution of the total effect and compare our results with those of other country studies. For convenience, we assume that a rise in expenditure resulting from higher product prices is equivalent to a decrease in real income.

\section{A. Direct Effect}

Household fuel expenditure is predominantly for kerosene and gasoline, which account for 95 percent of total spending on fuel. On average, 1.45 percent of household expenditures are allocated for kerosene and 1 percent for gasoline (Table 4). Diesel and other sources of energy represent a relatively small share of household consumption.

The consumption of fuel products differs significantly across households according to their expenditure levels (Table 4). The poorest households have the highest average budget share for kerosene (2 percent). As expenditure per capita increases, budget shares for kerosene decrease. Other fuel products and sources of energy are disproportionately consumed by wealthy households. However, the bottom quintile seems to consume more diesel than the second and third quintiles, perhaps because diesel is often used in agricultural activities, in which poor households are mainly concentrated. 
Given the pattern of budget shares, the rising kerosene price has a slightly regressive effect on income, whereas an increase in the gasoline price is almost progressive. As we mentioned previously, budget shares give an indication of the price elasticity of households' real income. The bottom quintile will experience the biggest decrease in income following a rise in the kerosene price and the lowest decrease in income when the gasoline price goes up. The distributional effects of the rise in diesel prices are almost negligible for the three bottom quintiles.

Table 4. Household Budget Shares of Energy Spending by Product (percent of total spending)

\begin{tabular}{crrrrr}
\hline Quintile & Kerosene & Gasoline & \multicolumn{1}{c}{ Diesel } & Charcoal & Electricity \\
\hline Top & 0.88 & 1.98 & 0.10 & 0.91 & 1.47 \\
Fourth & 1.30 & 1.07 & 0.06 & 0.54 & 0.45 \\
Third & 1.47 & 0.67 & 0.01 & 0.29 & 0.16 \\
Second & 1.54 & 0.68 & 0.01 & 0.10 & 0.07 \\
Bottom & 2.04 & 0.61 & 0.04 & 0.06 & 0.01 \\
\hline All & 1.45 & 1.00 & 0.04 & 0.38 & 0.43 \\
\hline
\end{tabular}

Source: Mali, 2000-01 household survey.

Notes: Shares are calculated using data from the 2000-01 household survey. Quintiles are based on the national distribution of consumption per adult equivalent.

The direct expenditure effect of the rise in oil prices is modest, and its distribution follows a nonlinear pattern. Indeed, the lowest-quintile households are more affected than households in all other quintiles except those in the top one (Table 5). A 34 percent rise in the prices of all oil products leads to a 0.9 percent decrease in real income for the bottom quintile, while the income of households in the top quintile drops by 1 percent. Intermediate quintiles experience a smaller decrease in income than the top and bottom quintiles. Although poor people lose less in nominal terms than other income groups (Table 5, column 3), the decrease in their real income is relatively high given their low level of expenditures.

Table 5. Direct Expenditure Effects of Oil Price Increases

\begin{tabular}{|c|c|c|c|c|c|c|c|}
\hline \multirow[b]{2}{*}{$\underline{\text { Quintile }}$} & \multirow{2}{*}{$\begin{array}{l}\text { Expenditure } \\
\text { Effect } \\
\text { (percent of } \\
\text { spending) } \\
\end{array}$} & \multirow{2}{*}{$\begin{array}{l}\text { Expenditure Per } \\
\text { Capita } \\
\text { (Thousands of CFA francs) }\end{array}$} & \multirow{2}{*}{$\begin{array}{l}\text { Nominal Expenditure } \\
\text { Effect } \\
\text { (Thousands of CFA francs) }\end{array}$} & \multicolumn{4}{|c|}{$\begin{array}{c}\text { Subsidy Share } \\
\text { (In percent) }\end{array}$} \\
\hline & & & & Products & Kerosene & Gasoline & Diesel \\
\hline Top & 1.0 & 316 & 3.6 & 43.5 & 19.2 & 59.0 & 71.1 \\
\hline Fourth & 0.8 & 152 & 1.3 & 19.9 & 22.4 & 18.3 & 17.0 \\
\hline Third & 0.7 & 100 & 0.8 & 14.1 & 23.0 & 8.3 & 2.5 \\
\hline Second & 0.8 & 70 & 0.5 & 11.5 & 17.6 & 7.6 & 3.3 \\
\hline Bottom & 0.9 & 42 & 0.4 & 11.2 & 17.8 & 6.7 & 6.1 \\
\hline All & 0.9 & 136 & 1.3 & 100.0 & 100.0 & 100.0 & 100.0 \\
\hline
\end{tabular}

Source: Mali, 2000-01 household survey.

Notes: Shares are calculated using data from the 2000-01 Household survey. Expenditure effects are obtained by multiplying the sum of oil product spending shares (kerosene, gasoline and diesel) by the oil price increase $(0.34)$. Nominal expenditure effect is equal to the expenditure per capita multiplied by the expenditure effect. Quintiles are based on the national distribution of consumption per adult equivalent. Average expenditure per capita is based on annual per adult equivalent consumption and is in thousand of CFA. 
Nonparametric estimates ${ }^{11}$ support the above findings (Figure 5). As we found previously (Tables 4 and 5), the direct expenditure effect of a rise in kerosene prices decreases when the expenditure per capita level increases, whereas the opposite is true for a rise in gasoline or diesel prices. For all oil products, the combined direct effect of price increases shows a Ushaped relationship with the per capita expenditure level.

Regardless of the oil product considered, the evidence is clear that rich households benefit more from price subsidies than poor households (Table 5). Assuming that all oil prices are subsidized at the same rate, the bottom three quintiles receive less than their population shares while the top quintile receives more than double its population share. When we assume that only the price of kerosene is subsidized, the share of subsidies accruing to the three bottom quintiles increases, but the bottom and the second quintiles still receive less than their population shares. Obviously, gasoline and diesel subsidies disproportionately benefit the richest households. These results suggest that the removal of oil subsidies is progressive. They are consistent with the results of other studies that find that oil subsidies are not the most efficient means of protecting the poor against higher oil prices.

Figure 5. Direct Expenditure Effects: A Nonparametric Representation
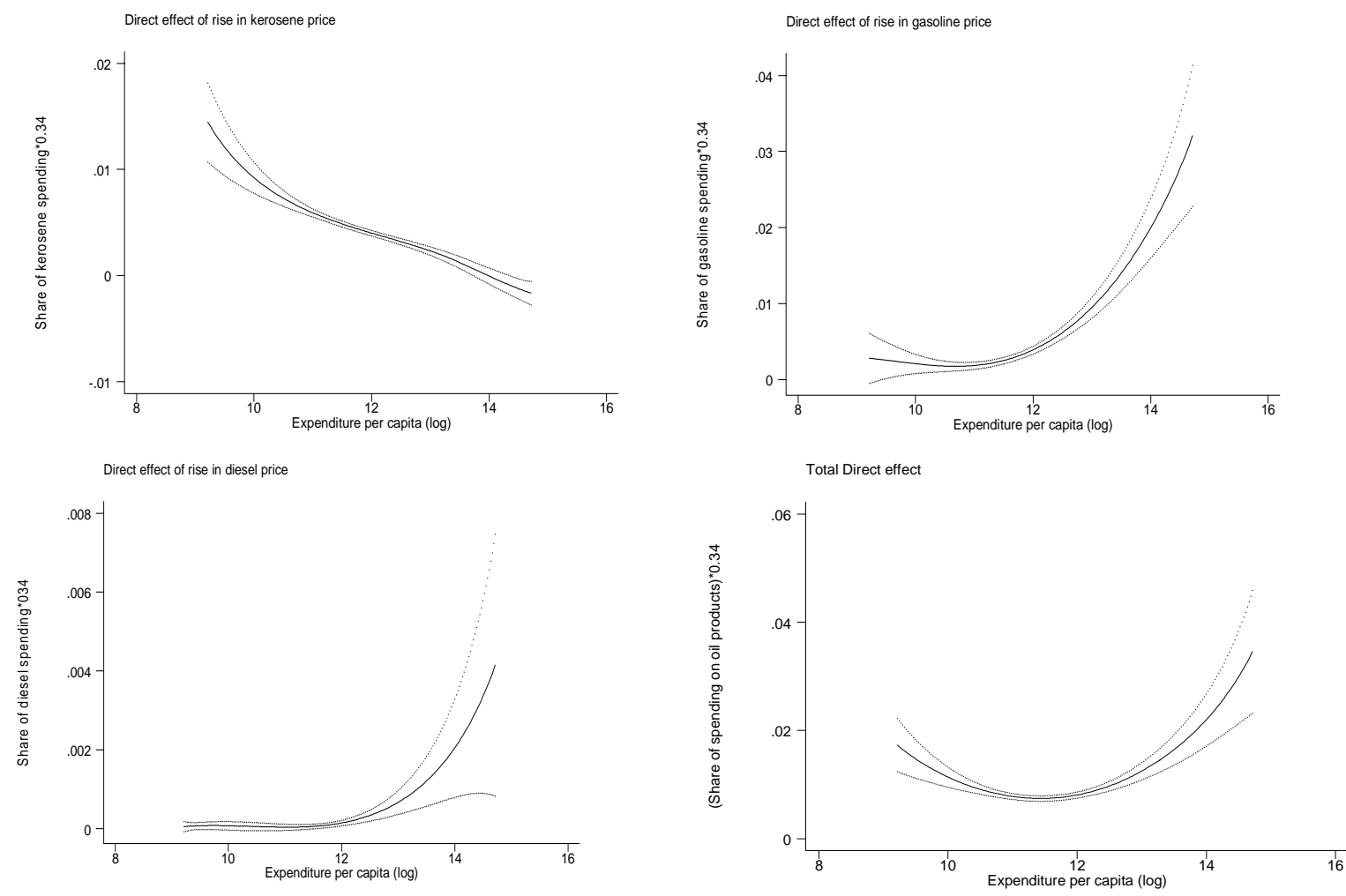

Notes: Author's calculations, Epanechnikov kernel, bandwidth=1;

\footnotetext{
11 This approach used by Deaton (1997) allows to compute the average expenditure effect at each level of expenditure per capita and as a result to look behind the average by quintile. It consists in assessing the relationship between the expenditures effects and the level of expenditure per capita without assuming a particular functional form.
} 
The dotted lines depict 95 percent confidence intervals obtained by bootstrap estimates.

In both rural and urban areas, patterns of distributional effects are similar to those of the whole sample, but urban households are, on average, more affected than rural households (Table 6). A 34 percent rise in oil prices increases the average expenditure of urban households by 0.98 percent compared with 0.8 percent for rural households. However, rural households are more affected by the rising kerosene price because they spend more on kerosene (1.57 percent) than urban households (1.12 percent), probably because electrification in rural areas is minimal.

Table 6. Budget Shares of Petroleum Products and Direct Expenditure Effects, by Quintile and Urban/Rural (in percent, unless otherwise noted)

\begin{tabular}{ccccccc}
\hline Urban & & & & & & \\
\hline
\end{tabular}

\begin{tabular}{ccccccc}
\hline Rural & & & & & & \\
\end{tabular}

Source: Mali, 2000-01 household survey.

Notes: Shares are calculated using data from the 2000-01 Household survey. The expenditure effect is obtained by multiplying the sum of oil product spending shares by the oil price increase (0.34). Quintiles are based on the national distribution of consumption per adult equivalent. Average expenditure per capita is based on annual per adult equivalent consumption and is in thousand of CFA.

\section{B. Indirect Effect}

Although poor households devote a relatively small share of their budgets to transport and electricity, they are likely to be affected indirectly if food prices are highly sensitive to oil prices. Table 7 classifies goods consumed by households into nine broad categories. To identify which commodities are more important for poor households than for wealthy households, we divide the budget share of the bottom quintile by the budget share of the top 
quintile. Although this approach does not take into account intermediate quintiles, it may provide useful information about commodities for which price increases are more harmful to the poor than the more well-to-do. For instance, the poor spend more on food products than rich households; therefore, poor households are likely to be more negatively affected by food price increases. Oil price increases will hurt the poor slightly less than the rich, while housing, water, and energy price increases will primarily affect rich households.

Table 7. Share of Household Expenditure on Different Goods and Services by Household Income Quintile (in percent)

\begin{tabular}{|c|c|c|c|c|c|c|c|c|}
\hline \multirow[b]{2}{*}{ Household expenditures } & \multicolumn{5}{|c|}{$\begin{array}{c}\text { Household Income } \\
\text { Quintile }\end{array}$} & \multirow{2}{*}{\multicolumn{2}{|c|}{$\begin{array}{r}\text { Relative } \\
\text { measure }\end{array}$}} & \multirow[b]{2}{*}{ Rank } \\
\hline & Top & 4th & 3rd & 2nd & Bottom & & & \\
\hline Food & 67.5 & 75.4 & 80.2 & 82.1 & 84.0 & 77.8 & 1.24 & 1 \\
\hline Education & 0.5 & 0.4 & 0.3 & 0.4 & 0.5 & 0.4 & 0.91 & 2 \\
\hline Oil products & 3.0 & 2.4 & 2.2 & 2.2 & 2.7 & 2.5 & 0.90 & 3 \\
\hline Clothing & 5.7 & 5.3 & 5.3 & 5.5 & 5.0 & 5.4 & 0.88 & 4 \\
\hline Health & 2.4 & 2.4 & 1.9 & 1.8 & 1.6 & 2.0 & 0.66 & 5 \\
\hline Furniture and household accessories & 1.4 & 1.4 & 1.2 & 0.9 & 0.8 & 1.1 & 0.57 & 6 \\
\hline Other Goods and Services & 6.5 & 4.9 & 4.2 & 3.5 & 2.8 & 4.4 & 0.42 & 7 \\
\hline Transport and Communication & 4.9 & 2.8 & 1.6 & 2.2 & 1.7 & 2.6 & 0.35 & 8 \\
\hline Housing, Water and Energy & 8.0 & 5.1 & 3.2 & 1.4 & 1.0 & 3.7 & 0.12 & 9 \\
\hline
\end{tabular}

Source: Mali, 2000-01 household survey.

Notes: Shares are calculated using data from the 2000-01 household survey. Relative measure is derived as the budget share of the bottom quintile divided by the budget share of the top quintile. Quintiles are based on the national distribution of consumption per adult equivalent.

Sectors experience significant price changes depending on their input-output linkages with the petroleum sector (Figure 6). Following a 34 percent rise in oil prices, services to the agricultural sector experience the largest price increase (11 percent), followed by metallurgy products (7.44 percent) and transport and telecommunication (7.22 percent). These increases were estimated using the input-output matrix under the assumption that cost increases caused by higher oil prices are fully passed through to output prices, except to the prices of electricity and public services, which are assumed to be controlled by the government.

The bulk of the indirect expenditure effect comes through increases in food expenditures, although food price hikes are relatively small (Table 8). Expenditure effects for foods are the largest, mainly because of their high budget shares. Likewise, the expenditure effects for transport and telecommunication are also large, albeit because of high price increases rather than high budget shares. 
Figure 6. Price Changes of Commodities in Other Sectors Due to a 34 Percent Increase in Oil Prices (in percent)

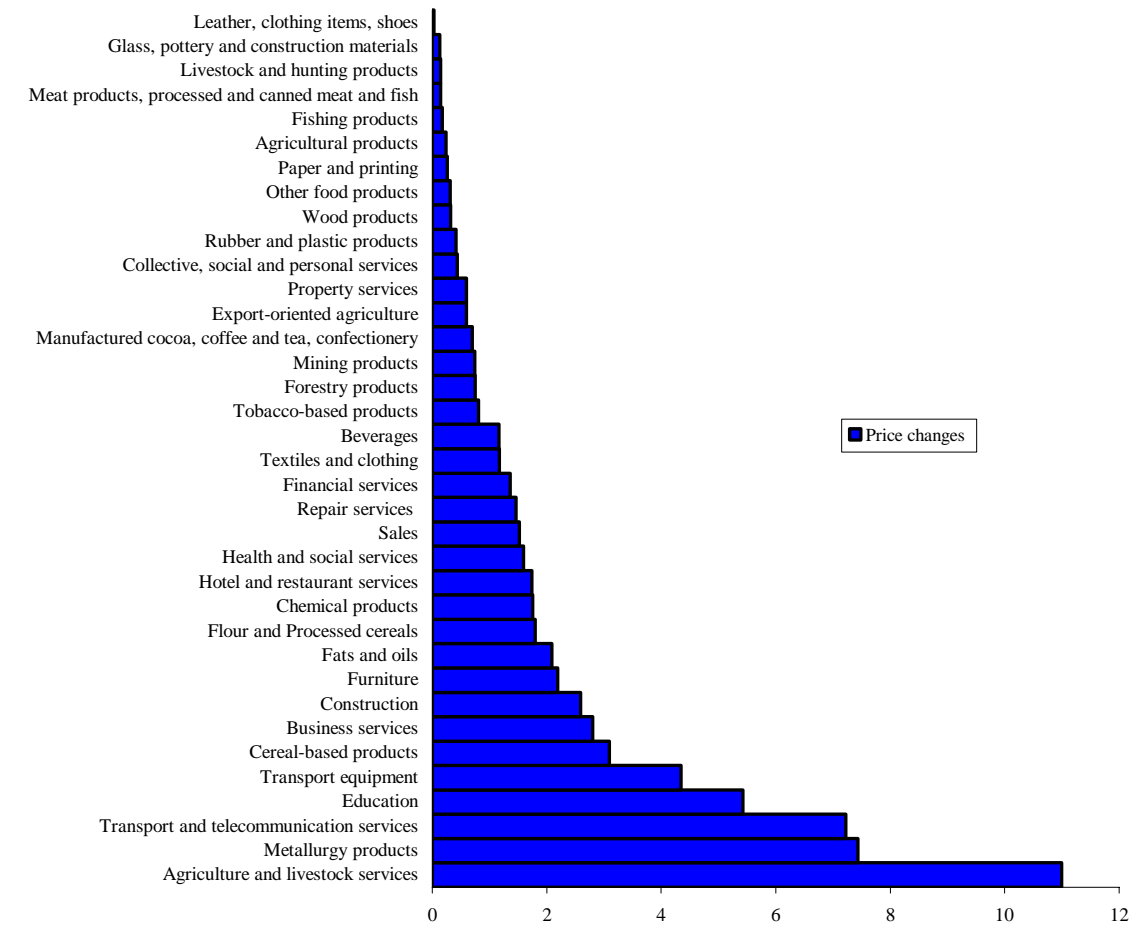

Source: Author's calculations based on the 1998 input-output matrix.

Table 8. Indirect Price and Expenditure Effects by Sector (In percent)

\begin{tabular}{lrrr}
\hline & Price & \multicolumn{2}{r}{ Budget Expenditure } \\
Sector & change & share & effect \\
\hline Flour and processed cereals & 1.80 & 13.40 & 0.24 \\
Fatty substances & 2.09 & 3.80 & 0.08 \\
Food products & 0.24 & 31.10 & 0.08 \\
Transport and telecommunication services & 7.22 & 0.90 & 0.07 \\
Textile and clothing & 1.17 & 4.50 & 0.05 \\
Chemical products & 1.75 & 2.20 & 0.04 \\
Cereal-based products & 3.10 & 1.10 & 0.04 \\
\hline
\end{tabular}

Source: Mali, 2000-01 household survey.

Notes: Shares are calculated using data from the 2000-01 household survey. The expenditure effect is obtained by multiplying the price change by the budget share. Only sectors with an average expenditure effect greater than 0.03 percent are presented.

Indirect expenditure effects of oil price increases are modest and slightly regressive, with the poor experiencing the biggest expenditure rises (Table 9). This is the case because of the relatively high food budget shares of poor households and the assumption that the electricity price is fixed for wealthy households. These arguments also help explain the fact that rural households are more affected than urban households by oil price increases. 
As for the direct effect, the intermediate quintiles experience fewer indirect expenditure effects than the bottom and the top quintile, as evidenced in the nonparametric estimates (Figure 7); the confidence interval of the right tail of the distribution is however relatively large.

As regards the oil subsidies associated with the indirect effect, rich households receive the highest share. Indeed, the share of oil subsidies accruing to the top quintile is three times larger than that accruing to the bottom quintile. ${ }^{12}$

Table 9. Indirect Expenditure Effects by Quintile, Rural and Urban (in percent)

\begin{tabular}{lrrrr}
\hline Quintile & All & Urban & Rural & $\begin{array}{r}\text { Subsidy } \\
\text { Share }\end{array}$ \\
\hline Top & 0.86 & 0.83 & 0.90 & 39.8 \\
Fourth & 0.78 & 0.75 & 0.80 & 19.4 \\
Third & 0.76 & 0.70 & 0.78 & 15.4 \\
Second & 0.83 & 0.71 & 0.84 & 13.7 \\
Bottom & 0.88 & 0.71 & 0.88 & 11.8 \\
\hline All & 0.82 & 0.78 & 0.84 & 100.0 \\
\hline
\end{tabular}

Notes: Quintiles are based on the national distribution of consumption per adult equivalent. Numbers are derived by aggregating the expenditure effects in Table 8 for each household.

Figure 7. Indirect Expenditure Effects: A Nonparametric Representation

All Households

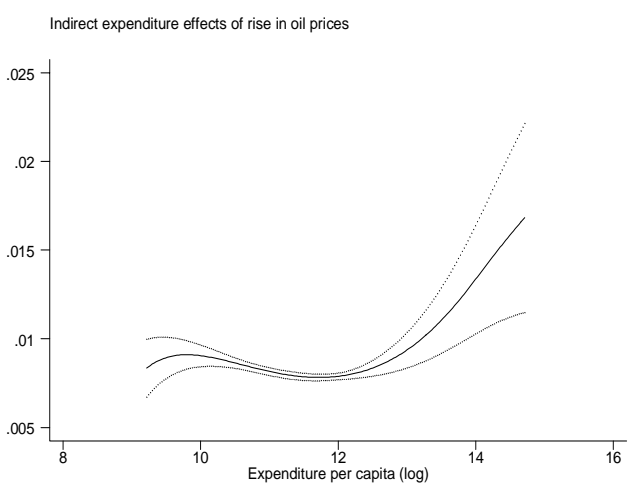

Urban Households

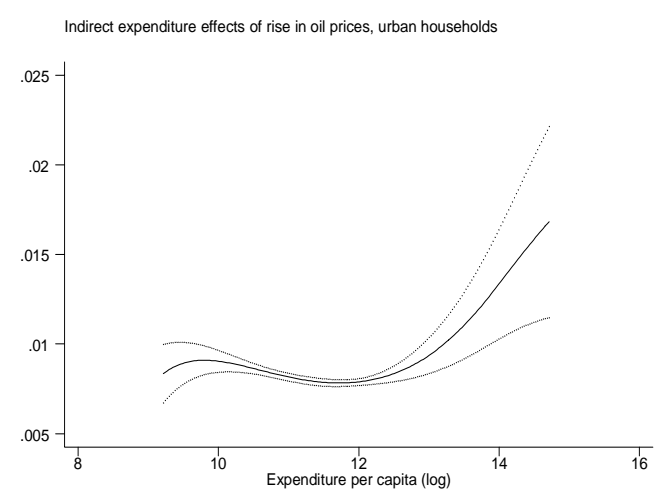

12 In contrast to subsidy shares linked with the direct effect, those related to the indirect effect depend on the subsidy rate. From March 2003 to March 2005, international oil prices (in CFA francs) rose by 37.42 percent, while domestic oil prices increased by 16.64 percent. First, we compute the change in the prices of other goods following a 37.42 percent rise in oil prices. Second, we do the same thing for a 16.64 percent rise in oil prices. Finally, we calculate the difference between household expenditures under the two scenarios, which is equivalent to the amount of subsidies received by each household. Since petroleum products are aggregated in the inputoutput table, we are unable to compute the subsidy shares by quintile for each oil product. However, we could assume that subsidies associated with indirect expenditure effects are negligible when only kerosene is considered. 
Rural Households

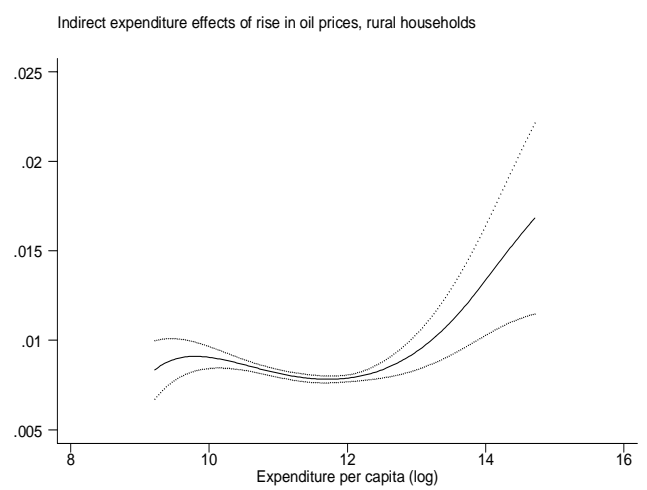

Notes: $\quad$ Author's calculations, Epanechnikov kernel, bandwidth=1;

The dotted lines depict 95 percent confidence intervals obtained by bootstrap estimates.

\section{Total Effect}

Total expenditure effects yield a conclusion similar to the direct effects, which account for half of the total effect (Table 10). First, oil price increases have a limited impact on household expenditures, with urban households being more affected than rural households. Second, rich households benefit disproportionately from oil subsidies because they consume a larger share of oil products. Third, the highest incidences of rising oil prices are borne by the bottom and the top quintiles (Figure 8). Finally, the relative share of the direct effect is roughly equal to that of the indirect effect (Table 11). Although intermediate oil consumption (76 percent of total) is nearly four times more than final household oil consumption (20 percent of total), indirect and direct effects are similar because a large proportion of intermediate oil consumption is in the electricity sector where prices are assumed fixed, is in the mining sector where production is exported, or is consumed by the public administration.

Wealthy households benefit not only from oil subsidies but also from controlled electricity prices (Table 12). When we remove the assumption of a fixed electricity price, a 34 percent rise in oil prices leads to a 10.72 percent increase in the electricity price. The distributional effects show that the removal of electricity subsidies is slightly progressive. However, the urban poor are likely to be affected negatively by a higher electricity price and therefore need to be protected. 
Table 10. Total Direct and Indirect Expenditure Effects by Quintile, Urban and Rural (in percent)

\begin{tabular}{|c|c|c|c|c|}
\hline Quintile & All & Urban & Rural & Subsidy share \\
\hline Top & 1.86 & 1.94 & 1.73 & 41.7 \\
\hline Fourth & 1.61 & 1.69 & 1.56 & 19.6 \\
\hline Third & 1.50 & 1.42 & 1.51 & 14.7 \\
\hline Second & 1.59 & 1.45 & 1.60 & 12.5 \\
\hline Bottom & 1.79 & 1.74 & 1.79 & 11.5 \\
\hline All & 1.67 & 1.76 & 1.64 & 100.0 \\
\hline
\end{tabular}

Note: Quintiles are based on the national distribution of consumption per adult equivalent.

Figure 8. Total Expenditure Effects: A Nonparametric Representation
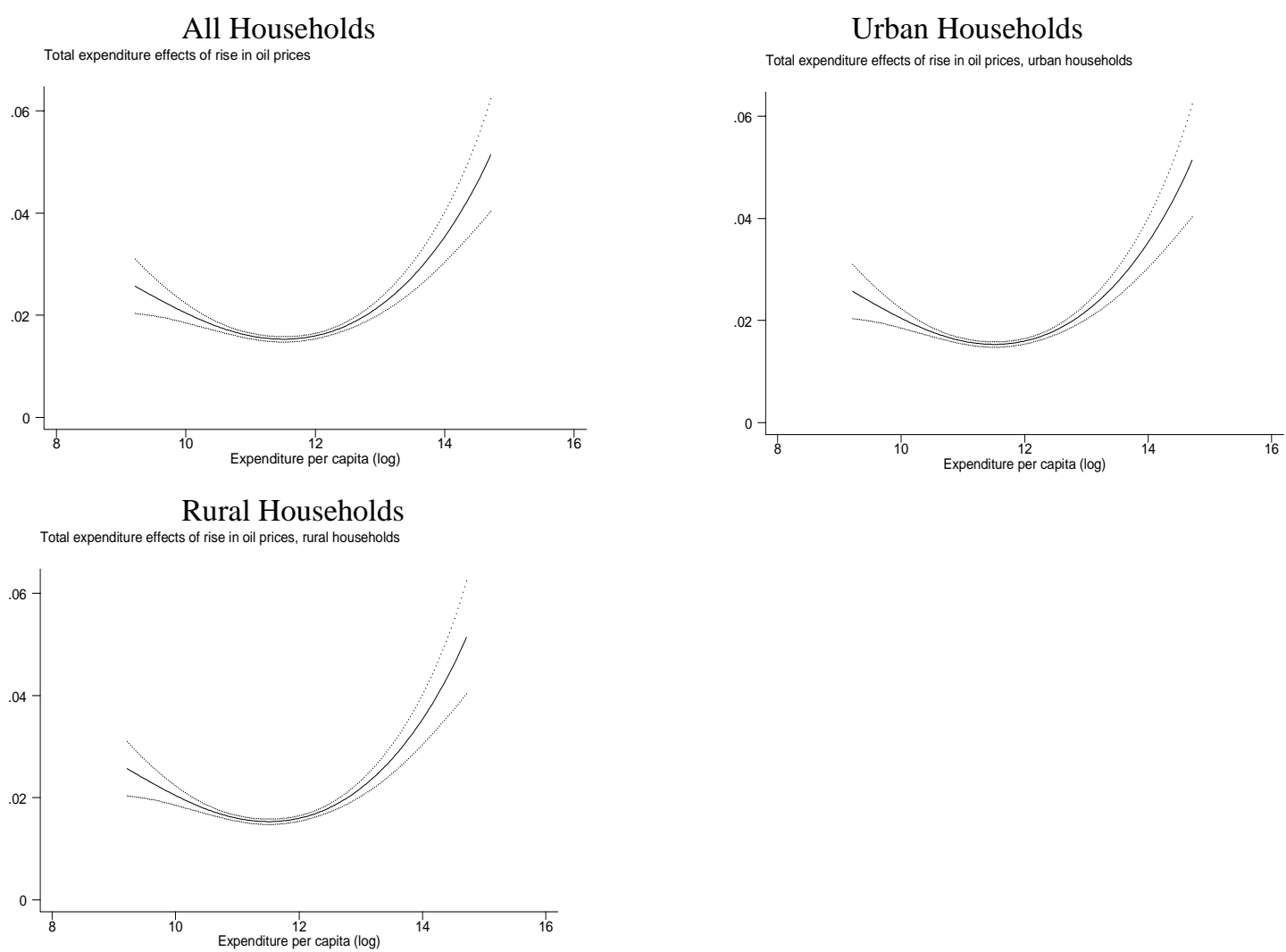

Notes: Author's calculations, Epanechnikov kernel, bandwidth=1;

The dotted lines depict 95 percent confidence intervals obtained by bootstrap estimates. 
Table 11. Relative Importance of Direct and Indirect Effects (in percent)

\begin{tabular}{|c|c|c|c|c|c|}
\hline Quintile & $\begin{array}{l}\text { Direct } \\
\text { Effect }\end{array}$ & $\begin{array}{c}\text { Indirect } \\
\text { Effect }\end{array}$ & $\begin{array}{l}\text { Total } \\
\text { Effect }\end{array}$ & $\begin{array}{c}\text { Share of } \\
\text { Direct Effect }\end{array}$ & $\begin{array}{c}\text { Share of } \\
\text { Indirect Effect }\end{array}$ \\
\hline Top & 1.01 & 0.86 & 1.86 & 54.3 & 46.2 \\
\hline Fourth & 0.83 & 0.78 & 1.61 & 51.6 & 48.5 \\
\hline Third & 0.73 & 0.76 & 1.50 & 48.7 & 50.7 \\
\hline Second & 0.76 & 0.83 & 1.59 & 47.8 & 52.2 \\
\hline Bottom & 0.91 & 0.88 & $1.7 \mathrm{~S}$ & 50.8 & 49.2 \\
\hline All & 0.85 & 0.82 & 1.67 & 50.9 & 49.1 \\
\hline
\end{tabular}

Note: Quintiles are based on the national distribution of consumption per adult equivalent.

Table 12. Indirect Expenditure Effects by Quintile, Rural and Urban: Distribution Effects of Controlled Electricity Price (in percent)

\begin{tabular}{|c|c|c|c|c|c|c|c|c|c|}
\hline \multirow[b]{2}{*}{ Quintile } & \multicolumn{3}{|c|}{ Noncontrolled Electricity Price (1) } & \multicolumn{3}{|c|}{ Controlled Electricity Price (2) } & \multicolumn{3}{|c|}{ Difference (1)-(2) } \\
\hline & All & Urban & Rural & All & Urban & Rural & All & Urban & Rural \\
\hline Top & 1.24 & 1.32 & 1.11 & 0.86 & 0.83 & 0.90 & 0.38 & 0.49 & 0.20 \\
\hline Bottom & 1.04 & 1.09 & 1.04 & 0.88 & 0.71 & 0.88 & 0.17 & 0.38 & 0.16 \\
\hline All & 1.06 & 1.20 & 1.01 & 0.82 & 0.78 & 0.84 & 0.24 & 0.42 & 0.17 \\
\hline
\end{tabular}

Note: Quintiles are based on the national distribution of consumption per adult equivalent.

\section{Results for Mali Versus Other Countries}

The estimated average expenditure effect of oil price increases in Mali falls in the range of findings that have emerged from other country studies. ${ }^{13}$ A 20 percent increase in oil prices leads to 1 percent rise in household expenditures in Mali, ${ }^{14}$ which is similar to that for Pakistan (0.85 percent) but significantly lower than that for Ghana (3.4 percent). The difference between expenditure effects in Mali and Ghana results from higher oil subsidies and the fact that households in Ghana consume more oil products. For instance, the kerosene budget share is 3.5 percent in Ghana, compared with 1.45 percent in Mali.

As for Mali, studies of other countries find that oil price hikes affect urban households more than rural households. Likewise, studies reveal that oil subsidies benefit rich households more than poor households. Therefore, the removal of oil price subsidies would be a progressive and economically desirable measure. However, increases in oil prices should be accompanied by well-targeted transfer programs to compensate the poorest households for the adverse effects of higher oil prices.

\footnotetext{
${ }^{13}$ See Appendix II.

14 The impact estimated using the input-output approach is linearly proportional to the level of the price increase. In Mali, a 34 percent rise in oil prices leads to a 1.67 percent decrease in real income, and so real income will decrease by 0.98 percent if oil prices rise by 20 percent.
} 
Regarding distributional effects across income groups, contrasting results emerge from country studies. Although oil price rises are progressive in South Africa and Indonesia, they are regressive in Ghana, the Islamic Republic of Iran, and Pakistan. Mali and Mozambique show a different pattern, with the bottom quintile feeling the impact slightly more than all other quintiles except the top one, most likely because of different price increases for oil products. If the kerosene price increase accounts for a significant share of the average oil price hike, then it, combined with high kerosene shares in their budgets, will hurt the poor. ${ }^{15}$ However the Pakistan case study is puzzling because the oil price increase is regressive even though the kerosene price is held constant. Further investigation reveals that the poor are affected by increases in food prices (milled grains, vegetable oils, wheat, and so on) which are sensitive to transport costs. ${ }^{16}$

The relative importance of the direct effect varies across countries. In Mali, the direct effect of the oil price increase accounts for 50 percent of the total effect, compared with 20 percent in Ghana. This disparity is explained by the fact that households in Ghana directly consume 6.2 percent of petroleum products, a level that is three times less than households in Mali, which consume 20 percent of petroleum products. Also, indirect effects are higher in Ghana because households consume more energy-intensive products. In particular, transport costs represent 3.2 percent of household expenditures in Ghana and only 0.9 percent in Mali.

\section{CONCLUSiOn AND Policy IMPLiCATIONS}

Oil price increases have a clearly adverse yet modest impact on household expenditures in Mali. This results suggests that a 34 percent rise in oil prices leads to a 1.67 percent average increase in household expenditures, with the impact on rural households (1.64 percent) being slightly smaller than that on urban households (1.76 percent). The indirect effect caused by the rise in the prices of other goods and services is calibrated through input-output linkages with the petroleum sector; it represents roughly 50 percent of the total effect.

Although the lowest and the highest expenditure quintiles are most adversely affected by oil price rises, the benefits of blanket subsidies accrue largely to the nonpoor. Mali therefore stands to reap major gains by trying to target subsidies to achieve its poverty-reduction objectives. The impact of fuel prices on household budgets had a U-shaped relationship with expenditure per capita. The households in bottom quintile experienced a 1.79 percent rise in expenditures, which is smaller than the impact on households in the top quintile but larger than the impact on households belonging to the intermediate quintiles. However, given that higherincome groups consume the largest share of oil products, they benefit the most from implicit subsidies on oil consumption. Likewise, control of the electricity price to smooth the impact of oil price increases benefits rich households rather than poor households.

\footnotetext{
${ }^{15}$ For instance, in Ghana, a 50 percent increase in the average oil price resulted from a 49 percent price increase for kerosene, 17 percent for gasoline, and 108 percent for LPG (liquefied petroleum gas). In the Islamic Republic of Iran, the increase in kerosene price is three times higher than that of gasoline. For Mali, increases in all oil product prices are equal.

${ }^{16}$ In fact, the simulation of a 33 percent rise in oil prices is a weighted average of a 10 percent decrease in the gasoline price and a 67 percent increase in the price of diesel.
} 
However, these results should be interpreted as representing the maximum short-run impact of the oil price increase. In the medium and long run, households and firms will adjust their demand for oil products, leading to smaller expenditure effects. The adjustment is made through the price elasticity of demand for oil products. That is, to the extent that consumers and producers reduce their demand for oil, either by switching to a different fuel or by switching to other goods or products, the long-run expenditure effect will be smaller than the short-run impact. For developing countries, the long-run elasticity is estimated at about 0.25 (Gately and Huntington, 2001), which implies that about 25 percent of the impact calculated above might be offset by adjustment in domestic demand. In practice, these second-order effects are complex, and estimating their magnitude requires a CGE model with a set of supply and demand elasticities.

The policy implications of our results are clear: neither oil subsidies nor electricity subsidies are effective in protecting the poor. Nevertheless, given that rising oil prices harm the poor, particularly in the short run, it is necessary to try to mitigate the impact through well-targeted social safety nets using some of the resources generated through subsidy reform. First, a kerosene subsidy or the use of coupons could help to soften the impact of oil price shocks on the poor. These subsidies should be made available on a temporary basis and in a transparent manner to discourage the direct diversion of subsidized kerosene to other purposes. Second, the government could generate additional financial resources through subsidy reform to finance social spending, such as education and health programs, which are more beneficial to the poor. Third, because the elimination of electricity subsidies hurts rich households but also the urban poor, a subsidized rate could be granted up to modest levels of consumption. This would prevent richer households from taking advantage of those subsidies and lessen poor households' incentive to switch to kerosene. Also, the withdrawal of electricity subsidies should be accompanied by a rural electrification program to expand the access of rural households to electricity; this may reduce their consumption of kerosene. Finally, the removal of subsidies can be politically difficult. One way to soften the impact is to clearly explain the rationale to the public and to introduce higher prices gradually according to a clear timetable. In the medium run, it would be desirable to allow market mechanisms to determine domestic oil prices and to promote the efficient use of fuel. 


\section{References}

Alves, Denisard C.O., and Rodrigo De Losso da Silveira Bueno, 2003, “Short-Run, LongRun and Cross Elasticities of Gasoline Demand in Brazil,” Energy Economics, Vol. 25 (March), pp. 191-99.

Bacon, Robert, 2005, “The Impact of Higher Oil Prices on Low-Income Countries and on the Poor,” UNDP/ESMAP Report (Washington: The World Bank).

Chabé-Ferret, Sylvain, 2005, “L’impact distributif des politiques agricoles des pays développés au Brésil: une analyse non paramétrique” (unpublished; ClermontFerrand: Centre d’Études et de Recherches sur le Développement International).

Clements, Benedict, Jung Hong-Sang, and Sanjeev Gupta, 2003, "Real and Distributive Effects of Petroleum Price Liberalization: The Case of Indonesia,” IMF Working Paper No. 03/204, (Washington: International Monetary Fund).

Coady, David, and David Newhouse, 2005 "Ghana: Evaluation of the Distributional Impacts of Petroleum Price Reforms,” Technical Assistance Report (unpublished; Washington: International Monetary Fund).

Cooper, John, 2003, "Price Elasticity of Demand for Crude Oil: Estimates for 23 Countries," OPEC Review, Vol. 27 (March), pp. 1-6.

Deaton, Angus, 1997, The Analysis of Household Surveys: A Microeconometric Approach to Development Policy (Baltimore: Johns Hopkins University Press for the World Bank).

Gately, Dermot, and Shane Streifel, 1997, “The Demand for Oil Products in Developing Countries,” World Bank Discussion Paper No. 359 (Washington).

Gately, Dermot, and Hillard G. Huntington, 2001, “The Asymmetric Effects of Changes in Price and Income on Energy and Oil Demand,” Economic Research Report (New York: Department of Economics, New York University).

Hope, Einar, and Balbir Singh, 1995, “Energy Price Increases in Developing Countries: Case Studies of Malaysia, Indonesia, Ghana, Zimbabwe, Colombia and Turkey,” World Bank Policy Research Working Paper No. 1442 (Washington).

International Monetary Fund (IMF), 2005, Regional Economic Outlook: Sub-Saharan Africa (Washington).

McDonald, Scott, and Melt van Schoor, 2005, “A Computable General Equilibrium (CGE) Analysis of the Impact of an Oil Price Increase in South Africa,” PROVIDE Working Paper No. 1 (Elsenburg: The Western Cape Department of Agriculture). 
Nicholson, Kit, Bridget O'Laughlin, Antonio Fransisco, and Virgulino Nhate, 2003, “Fuel Tax in Mozambique” Poverty and Social Impact Analysis (Washington: World Bank).

Simone, Alejandro, 2004, "Mali: Assessing the Poverty Impact of Macroeconomic Shocks" (unpublished; Washington: International Monetary Fund).

Townsend, Joy, 1998, “The Role of Taxation Policy in Tobacco Control,” in The Economics of Tobacco Control: Towards an Optimal Policy Mix, ed. by I. Abedian and others (Cape Town, South Africa: Applied Fiscal Research Center), pp. 85-101.

Valadkhani, Abbas, and William F. Mitchell, 2002, “Assessing the Impact of Changes in Petroleum Prices on Inflation and Household Expenditures in Australia,” Australian Economic Review, Vol. 35 (June), pp. 122-32.

Von Moltke, Anja, McKee Colin, and Trevor Morgan, 2004, eds., Energy Subsidies: Lessons Learned in Assessing Their Impact and Designing Policy Reforms (Sheffield, England: Greenleaf Publishing for United Nations Environment and Programme).

World Bank, 2001, “Pakistan: Clean Fuels,” ESMAP Report No. 246/01 (Washington: World Bank, Energy Sector Management Assistance Programme).

World Bank, 2003, “Iran: Medium Term Framework for Transition, Converting Oil Wealth to Development,” Economic Report No. 25848-IRN (Washington). 
The Model

Let $A$ be the input-output coefficient matrix: $A=\left[\begin{array}{ccc}a_{11} & \ldots & a_{1 n} \\ \vdots & \ddots & \vdots \\ a_{n 1} & \cdots & a_{n n}\end{array}\right]$

The price system under the Leontief input-output table posits that the price in a given sector $P_{i}$ (the producer price) depends on the input-output coefficients $a_{i j},{ }^{17}$ the prices of the required intermediate domestic and imported inputs, ${ }^{18}$ and the value added per unit of $\operatorname{output}\left(v_{i}\right)$ as follows:

$$
\begin{aligned}
& \left\{\begin{array}{l}
P_{1}=a_{11} \cdot P_{1}+a_{21} \cdot P_{2}+\cdots+a_{n 1} \cdot P_{n}+v_{1} \\
P_{2}=a_{12} \cdot P_{1}+a_{22} \cdot P_{2}+\cdots+a_{n 2} \cdot P_{n}+v_{2} \\
\cdots \\
P_{n}=a_{1 n} \cdot P_{1}+a_{2 n} \cdot P_{2}+\cdots+a_{n n} \cdot P_{n}+v_{n}
\end{array}\right. \\
& \Rightarrow\left[\begin{array}{c}
P_{1} \\
P_{2} \\
\ldots \\
P_{n}
\end{array}\right]=\left[\begin{array}{cccc}
a_{11} & a_{21} & \ldots & a_{n 1} \\
a_{12} & a_{22} & \ldots & a_{n 2} \\
\ldots & \ldots & \ldots & \ldots \\
a_{1 n} & a_{2 n} & \ldots & a_{n n}
\end{array}\right] \cdot\left[\begin{array}{c}
P_{1} \\
P_{2} \\
\ldots \\
P_{n}
\end{array}\right]+\left[\begin{array}{c}
v_{1} \\
v_{2} \\
\ldots \\
v_{n}
\end{array}\right] \\
& \Rightarrow P=A^{\prime} \cdot P+v \text {. }
\end{aligned}
$$

By putting sectors together according to price control and by partitioning $A^{\prime}$ into four matrices $A_{1}^{\prime}, A_{2}^{\prime}, A_{3}^{\prime}$ and $A_{4}^{\prime}$, we obtain :

$$
\left[\begin{array}{l}
P_{c} \\
P_{n c}
\end{array}\right]=\left[\begin{array}{ll}
A_{1}^{\prime} & A_{2}^{\prime} \\
A_{3}^{\prime} & A_{4}^{\prime}
\end{array}\right] \cdot\left[\begin{array}{l}
P_{c} \\
P_{n c}
\end{array}\right]+\left[\begin{array}{l}
v_{c} \\
v_{n c}
\end{array}\right]
$$

where $P_{c}$ is the $p \times 1$ column vector of the prices in the controlled sectors. $P_{n c}$ is the $(n-p) \times 1$ column vector of the prices in the noncontrolled sectors. $A_{1}^{\prime}$ is the $p \times p$ matrix of the input-output coefficients of the $p$ controlled sectors.

\footnotetext{
${ }^{17}$ Inputs include domestic goods as well as imported goods.

${ }^{18}$ Imported inputs are assumed to be perfectly competitive with domestic inputs.
} 
$A_{2}^{\prime}$ is the $p \times(n-p)$ matrix of the input requirements from the $n-p$ noncontrolled sectors for the production of one unit of output in each controlled sector.

$A_{3}^{\prime}$ is the $(n-p) \times p$ matrix of the input requirements from the $p$ controlled sectors for the production of one unit of output in each $n-p$ noncontrolled sectors.

$A_{4}^{\prime}$ is the $(n-p) \times(n-p)$ matrix of the input-output coefficients of the $n-p$ noncontrolled sector.

$v_{c}$ is the $p \times 1$ column vector of value added per unit of output in the controlled sectors.

$v_{n c}$ is the $(n-p) \times 1$ column vector of value added per unit of output in the noncontrolled sectors.

$n$ is the total number of sector and $p$ the number of controlled sectors.

The price system (5) gives:

$$
\left[\begin{array}{l}
P_{c} \\
P_{n c}
\end{array}\right]=\left[\begin{array}{l}
A_{1}^{\prime} \cdot P_{c}+A_{2}^{\prime} \cdot P_{n c}+v_{c} \\
A_{3}^{\prime} \cdot P_{c}+A_{4}^{\prime} \cdot P_{n c}+v_{n c}
\end{array}\right]
$$

As the prices in controlled sectors are set exogenously, we are only interested in the prices of noncontrolled sectors that are given by the following equation:

$$
P_{n c}=A_{3}^{\prime} \cdot P_{c}+A_{4}^{\prime} \cdot P_{n c}+v_{n c}
$$

Thus:

$$
P_{n c}=\left(I-A_{4}^{\prime}\right)^{-1} \cdot A_{3}^{\prime} \cdot P_{c}+\left(I-A_{4}^{\prime}\right)^{-1} \cdot v
$$

Assuming that factor prices are constant (therefore $v$ is constant), the change in prices in noncontrolled sectors is given as:

$$
\Delta P_{n c}=\left(I-A_{4}^{\prime}\right)^{-1} \cdot A_{3}^{\prime} \cdot \Delta P_{c} .
$$


Distributional Effects of Oil Price Changes: Selected Country Studies

\begin{tabular}{|c|c|c|c|c|}
\hline Study/Author & Country & Context & Data & $\begin{array}{c}\text { Main results for a } 20 \text { percent increase in } \\
\text { average oil prices (unless otherwise specified) }\end{array}$ \\
\hline \multicolumn{5}{|c|}{ I. Input-Output Approach } \\
\hline $\begin{array}{l}\text { Coady and } \\
\text { Newhouse (2005) }\end{array}$ & Ghana & $\begin{array}{l}\text { The application of a new } \\
\text { pricing formula requires, } \\
\text { on average, a } 50 \text { percent } \\
\text { increase in pump prices. }\end{array}$ & $\begin{array}{l}\text { The } 1999 \text { Living } \\
\text { Standard Survey and } \\
\text { the } 1993 \text { Social } \\
\text { Account Matrix } \\
\text { (SAM). }\end{array}$ & $\begin{array}{l}\text { The average real income decreases by } 3.4 \\
\text { percent, with the poor being the most affected } \\
\text { ( } 3.64 \text { percent). However, the removal of } \\
\text { subsidies is a progressive policy. The indirect } \\
\text { effect accounts for } 80 \text { percent of the total } \\
\text { effect. }\end{array}$ \\
\hline $\begin{array}{l}\text { Valadkhani and } \\
\text { Mitchell (2002) }\end{array}$ & Australia & $\begin{array}{l}\text { Impact of a rise in oil } \\
\text { prices on price level and } \\
\text { income distribution }\end{array}$ & $\begin{array}{l}\text { The 1998-99 } \\
\text { Household Survey } \\
\text { and the } 1996-97 \\
\text { Input-Output table }\end{array}$ & $\begin{array}{l}\text { Based on budget share analysis, the authors } \\
\text { conclude that a rise in oil prices is regressive. } \\
\text { However, they did not provide a clear estimate } \\
\text { of real income effects. }\end{array}$ \\
\hline $\begin{array}{l}\text { World Bank } \\
\text { (2003) }\end{array}$ & $\begin{array}{l}\text { Iran, } \\
\text { Islamic } \\
\text { Rep. of }\end{array}$ & $\begin{array}{l}\text { A } 308 \text { percent rise in the } \\
\text { average energy price, } \\
\text { intended to bring all energy } \\
\text { prices to import parity }\end{array}$ & $\begin{array}{l}\text { The 1994-95 Input- } \\
\text { Output table and the } \\
\text { corresponding } \\
\text { household survey. }\end{array}$ & $\begin{array}{l}\text { Households experience, on average, a } \\
1.98 \text { percent decrease in real income. The } \\
\text { effect is regressive because poorer households } \\
\text { are hit harder than better-off households, } \\
\text { especially in rural areas ( } 3.1 \text { percent for poor } \\
\text { households compared with } 1.92 \text { percent for } \\
\text { rich households). }\end{array}$ \\
\hline $\begin{array}{l}\text { ESMAP }^{19} \text { Report } \\
\text { (2001) }\end{array}$ & Pakistan & $\begin{array}{l}\text { Assessment of a } 33 \text { percent } \\
\text { rise in gasoline and diesel } \\
\text { prices; other oil products } \\
\text { remained unchanged. }\end{array}$ & $\begin{array}{l}\text { The 1989-90 Input- } \\
\text { Output table and the } \\
\text { 1996-97 Household } \\
\text { Survey. }\end{array}$ & $\begin{array}{l}\text { The cost of living of households increases by } \\
0.85 \text { percent on average. The impact is higher } \\
\text { for urban households ( } 0.90 \text { percent) than for } \\
\text { rural ( } 0.79 \text { percent). In both areas, the impact } \\
\text { is regressive, with the poor experiencing a } \\
1.15 \text { percent increase in expenditures. }\end{array}$ \\
\hline $\begin{array}{l}\text { Nicholson and } \\
\text { others (2003) }\end{array}$ & $\begin{array}{l}\text { Mozam- } \\
\text { bique }\end{array}$ & $\begin{array}{l}\text { Increase in oil tax to } \\
\text { improve road maintenance, } \\
\text { raise domestic revenue, } \\
\text { and reduce aid } \\
\text { dependency. }\end{array}$ & $\begin{array}{l}\text { Data come from the } \\
\text { 1993-94 Social } \\
\text { Account Matrix and } \\
\text { the } 1996-97 \\
\text { Household Survey. }\end{array}$ & $\begin{array}{l}\text { The increase in the average fuel price, } \\
\text { assuming kerosene remains tax-exempt, leads } \\
\text { to a } 0.42 \text { percent increase in the average } \\
\text { expenditure of households. The lowest quintile } \\
\text { feels the impact slightly more than all other } \\
\text { quintiles except the rich. The impact is } \\
\text { significantly higher on urban households than } \\
\text { on rural households. }\end{array}$ \\
\hline
\end{tabular}

\section{CGE Analysis}

\begin{tabular}{|c|c|c|c|c|}
\hline $\begin{array}{l}\text { McDonald and } \\
\text { van Schoor } \\
(2005)\end{array}$ & $\begin{array}{l}\text { South } \\
\text { Africa }\end{array}$ & $\begin{array}{l}\text { Simulation of various oil } \\
\text { price shocks. }\end{array}$ & $\begin{array}{l}\text { The model is } \\
\text { calibrated on data } \\
\text { from the } 2000 \text { SAM. }\end{array}$ & $\begin{array}{l}\text { The rise in oil prices is progressive. Poor } \\
\text { households tend to be less adversely affected } \\
\text { and rural households have a slightly smaller } \\
\text { drop in income than urban households ( } 0.76 \\
\text { percent versus } 0.83 \text { percent). }\end{array}$ \\
\hline $\begin{array}{l}\text { Clements, Hong- } \\
\text { Sang, and Gupta. } \\
\text { (2003) }\end{array}$ & Indonesia & $\begin{array}{l}\text { Assessment of real and } \\
\text { distributives effects of } \\
\text { petroleum price } \\
\text { liberalization in Indonesia. }\end{array}$ & $\begin{array}{l}\text { The model is } \\
\text { calibrated on data } \\
\text { from the } 1995 \text { SAM. }\end{array}$ & $\begin{array}{l}\text { A } 25 \text { percent increase in oil prices would lead } \\
\text { to a } 2.5 \text { percent decrease in average real } \\
\text { consumption. The impact is slightly } \\
\text { progressive because high-income groups are } \\
\text { the most affected, especially in urban areas. }\end{array}$ \\
\hline
\end{tabular}

\footnotetext{
${ }^{19}$ The Energy Sector Management Assistance Programme
} 